Article

\title{
Species Composition and Distribution of Jellyfish in a Seasonally Hypoxic Estuary, Hood Canal, Washington
}

\author{
BethElLee Herrmann * and Julie E. Keister \\ School of Oceanography, University of Washington, Box 357940, Seattle, WA 98195, USA; jkeister@uw.edu \\ * Correspondence: blh1975@uw.edu
}

Received: 20 December 2019; Accepted: 24 January 2020; Published: 29 January 2020

\begin{abstract}
Seasonal hypoxia ( $\leq 2 \mathrm{mg}$ dissolved oxygen $\mathrm{L}^{-1}$ ) can have detrimental effects on marine food webs. Recent studies indicate that some jellyfish can tolerate low oxygen and may have a competitive advantage over other zooplankton and fishes in those environments. We assessed community structure and distributions of cnidarian and ctenophore jellyfish in seasonally hypoxic Hood Canal, WA, USA, at four stations that differed in oxygen conditions. Jellyfish were collected in June through October 2012 and 2013 using full-water-column and discrete-depth net tows, concurrent with CTD casts to measure dissolved oxygen (DO). Overall, southern, more hypoxic, regions of Hood Canal had higher abundances and higher diversity than the northern regions, particularly during the warmer and more hypoxic year of 2013. Of fifteen species identified, the most abundant-the siphonophore Muggiaea atlantica and hydrozoan Aglantha digitale-reached peak densities > 1800 Ind $\mathrm{m}^{-3}$ and 38 Ind $\mathrm{m}^{-3}$, respectively. M. atlantica were much more abundant at the hypoxic stations, whereas $A$. digitale were also common in the north. Vertical distributions explored during hypoxia showed that jellyfish were mostly in the upper $10 \mathrm{~m}$ regardless of the oxycline depth. Moderate hypoxia seemed to have no detrimental effect on jellyfish in Hood Canal, and may have resulted in high population densities, which could influence essential fisheries and trophic energy flow.
\end{abstract}

Keywords: Puget Sound; dissolved oxygen; gelatinous zooplankton; community structure; species diversity; food webs

\section{Introduction}

Jellyfish, gelatinous zooplankton of the phyla Cnidaria (scyphozoans and hydrozoans) and Ctenophora (comb jellies), inhabit most marine environments from coastal waters to the deep-sea [1]. Composed of $\sim 95 \%$ water and $<1 \%$ carbon [2], jellyfish can range in size from microns to meters [3,4]. They are slow moving, yet have advanced predatory capabilities which, combined with short generation times, can lead to rapid population growth [5]. Well documented jellyfish invasions, causing trophic cascades and devastating fisheries [6], have motivated researchers to carefully examine the drivers that have supported these taxa for more than 500 million years [2]. Still, jellyfish dynamics in marine ecosystems remain understudied, particularly those of the many small species that do not form conspicuous aggregations yet typically outnumber larger species.

Reports of jellyfish blooms have increased in recent years, especially around heavily populated coastlines, suggesting degraded environmental triggers $[7,8]$. Hypoxia (dissolved oxygen concentration $\leq 2 \mathrm{mg} \mathrm{L}^{-1}$ ) is one of the triggers that has been implicated in increasing blooms [9]. While many marine taxa cannot survive hypoxia for an extended time, displaying stress or avoidance, some jellyfish can store excess oxygen in their mesoglea, decreasing their vulnerability to low oxygen concentrations $[10,11]$. Their reproduction can also become more successful in low oxygen bottom-water as there is less benthic competition for space where jellyfish planulae settle [12]. Furthermore, their effectiveness as predators may be enhanced during hypoxia, enabling higher growth rates [13,14]. 
Many jellyfish are known to be voracious predators, consuming hundreds to thousands of prey items per day [15]. Jellyfish compete with fish for zooplankton prey, while some also prey directly on fish eggs and larvae [16], elevating their trophic role to that of apex predators [17]. Certain hydroids create grazing pressures on the benthos where they consume diatoms, fecal pellets, and sinking particulate organic matter [18], effectively infiltrating two of the most critical pathways in the trophic structure-primary producers (phytoplankton) and primary consumers (zooplankton). Thus, hypoxia-resistant jellyfish could proliferate and out-compete fish for prey [16], redirecting energy flow through food webs [19].

Hood Canal, a sub-basin of Puget Sound, Washington, is a taxonomically diverse region that seasonally experiences hypoxic conditions. Carved by the Puget Lobe of the Cordilleran ice sheet [20], Hood Canal's $\sim 185 \mathrm{~m}$ deep basin and narrow inlet is fronted on its ocean end by a shallow glacial sill that inhibits circulation [21], making it a highly conducive environment for oxygen depletion. These bathymetric features, coupled with strong stratification and high primary productivity in spring and summer, lead to a seasonal decrease in bottom-water dissolved oxygen [22]. Flushing events, driven by tides and winds, temporarily replenish oxygen in fall and winter [23]. Such events can displace warmer, less dense, hypoxic bottom-water to mid and surface layers [22]), periodically causing fish kills.

In this study, we examined the species composition and diversity of jellyfish in Hood Canal, and explored their seasonal and spatial patterns in relation to dissolved oxygen to better understand jellyfish community dynamics and responses to hypoxia. We studied taxa that range in size from a few millimeters to almost a meter in diameter. We hypothesized that jellyfish would show increased abundance and diversity in regions of Hood Canal that experience seasonal hypoxia, changes which could indicate high predation on zooplankton, a competitive advantage over fishes, and a resultant shift in energy flow through the ecosystem.

\section{Materials and Methods}

\subsection{Field Methods}

Sampling was conducted on 10 cruises spaced every fourth week from early June to early October in 2012 and 2013. Four stations were sampled on each cruise: Dabob Bay (DB), Duckabush (DU), Hoodsport (HP), and Union (UN) (Figure 1). These sites represent a gradient in dissolved oxygen levels; two sites, UN and HP, were at the southern end of Hood Canal where hypoxia typically develops in summer, and two in the northern region, DU and DB, where oxygen levels usually remain higher. Two types of net tows were conducted which sampled mesozooplankton, including mesoplankton jellyfish $(0.2-20 \mathrm{~mm})$, or megaplankton jellyfish $(>20 \mathrm{~mm})$, as defined by Omori and Ikeda [24]. Oblique tows were conducted for mesozooplankton from the R/V Clifford A. Barnes using a $0.25 \mathrm{~m}^{2} \mathrm{HydroBios}$ MultiNet plankton sampler (five-net capacity) equipped with $200-\mu \mathrm{m}$ mesh nets and inner and outer flow meters to measure the water volume filtered and monitor for clogging. On one occasion (at DB in July 2013), a vertical ring net tow (200- $\mu \mathrm{m}$ mesh, $0.6-\mathrm{m}$ diameter) was used during a MultiNet failure. Tows were conducted through the whole water column (herein termed full-water-column tows) from 5 to $10 \mathrm{~m}$ off the bottom, either as one net or a set of $4-5$ depth-stratified nets. Since many zooplankton perform diel vertical migration, the full-water-column net tows were used to assess populations of jellyfish independent of diel migrations. Depth-stratified tows were conducted in both day and night, with nets opened and closed at specific depths chosen from oxygen profiles to assess distributions in relation to dissolved oxygen (DO). All samples were preserved in 5\% buffered formalin and returned to the laboratory for analysis. 


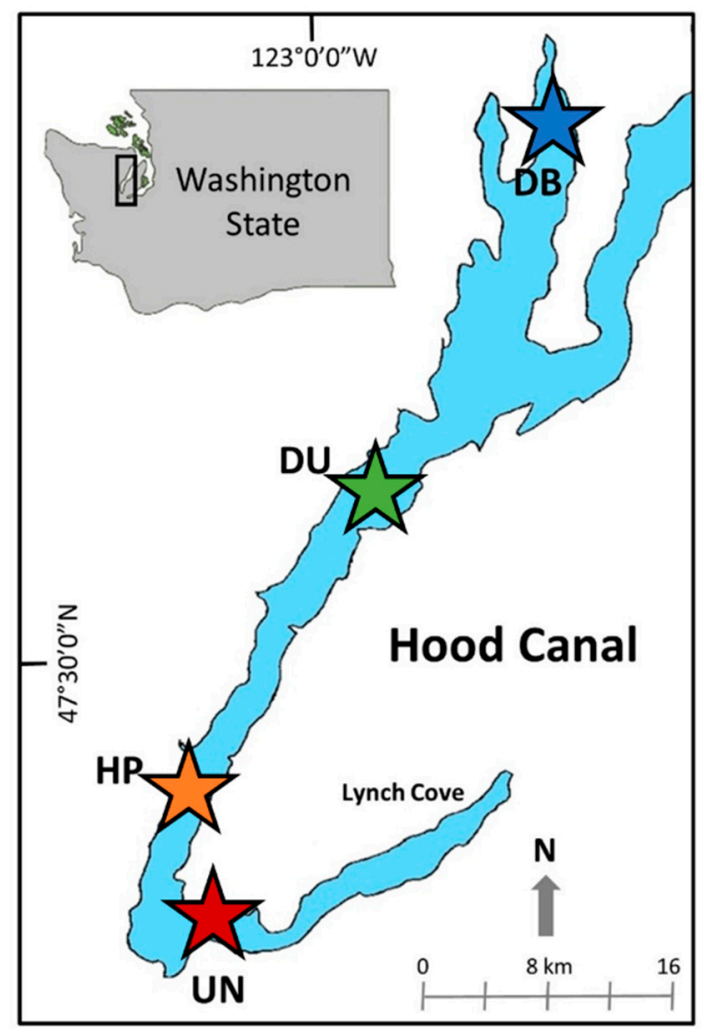

Figure 1. Map of Hood Canal in Puget Sound, Washington, USA. Stations sampled in 2012 and 2013 represent a range in dissolved oxygen conditions from north to south: Dabob (DB), Duckabush (DU), Hoodsport (HP), and Union (UN).

Densities of gelatinous megaplankton (large jellyfish) were estimated from Marinovich midwater trawls $(n=149)$ conducted from the $R / V$ Centennial using a 3.2-mm mesh codend, towed at a ship speed of 2-3 knots. Trawl depths were chosen based on where acoustic backscatter, monitored using a Simrad EK60 four-frequency system, was highest; trawls did not cover the entire water column, and set-depths varied with each trawl. The vertical opening of the trawl, estimated from Sensus Ultra depth probes deployed on the head and foot ropes, varied from 4.8 to $7.0 \mathrm{~m}$; distance trawled was calculated from GPS points using the Spherical Law of Cosines and used with the adjusted net opening to calculate net volume $\left(\mathrm{m}^{3}\right)$. Species identifications, abundances (number of Ind.), and wet weight mass $(\mathrm{kg})$ were recorded on board immediately after collection, after which densities (number of Ind. per $100 \mathrm{~m}^{3}$ ) and biovolumes (mL per $100 \mathrm{~m}^{3}$ ) were averaged across multiple day and night tows within each station-month-year. As set-depths varied, and trawl volumes could not be accurately assessed due to changes in the opening during trawling, these data should be considered as an index of large jellyfish abundance, used only to explore broad temporal and spatial patterns.

Casts of an annually-calibrated SBE 911plus CTD equipped with a Niskin rosette, SBE 43 Dissolved Oxygen (DO) sensor, and WET Labs ECO-AFL/FL fluorometer were conducted at each station prior to each day and night sampling period. The DO sensor was additionally calibrated by titrations following the modified Winkler Method $[25,26]$ on a Metrohm 765 Dosimat burette using discrete water samples collected from at least three depths per station.

\subsection{Laboratory Methods}

For this study, 40 full-water-column tows (one from each station-month-year combination) were analyzed for mesozooplankton and mesoplankton jellyfish species composition; in addition, 12 discrete-depth samples (three sets of four nets) were analyzed from where a portion of the water column was hypoxic to examine vertical distributions of jellyfish in relation to oxygen and prey distributions. 
Samples were split with a Folsom splitter (for jellyfish) or quantitatively diluted and subsampled using Stempel pipettes (for small prey taxa). Great care was taken to keep jellyfish structures intact. Unfortunately, the delicate ctenophore, Pleurobrachia bachei, was often only observed in pieces, and therefore quantified or measured from their robust gut-lining. Taxa were quantified and identified to the lowest taxonomic level (genus/species), with the exception of the colonial siphonophore, Muggiaea atlantica, which was further identified to individual zooid types to separate gastric components (nectophores, eudoxids with bracts, and separated bracts) from reproductive components (separated gonophores). Separated gonophores were not included in total abundances as these are egg-bearing zooids within the colony that have no grazing impact on the prey community [27]. In addition, measurements of bell diameter and height were recorded. To analyze prey abundances, species were grouped by genera or higher taxonomic group (i.e., calanoid or cyclopoid copepods, amphipods, krill, etc.). Densities were calculated as \# individuals $\mathrm{m}^{-3}\left(\mathrm{Ind} \mathrm{m}^{-3}\right)$ using the volume of water filtered by each net.

\subsection{Statistical Methods}

Species richness $(S)$, the Shannon-Wiener Diversity Index $(H)$ [28], evenness $\left(E_{H}\right)$, and the Simpson's Index of Diversity ( $\left.\mathrm{D}^{\prime}\right)$ [29] were calculated to assess temporal and spatial patterns in mesoplankton jellyfish species diversity. Patterns in species composition were explored using Nonmetric Multidimensional Scaling (NMS) ordinations in PC-ORD ${ }^{\mathrm{TM}} 7.06$ [30]. Sørensen (Bray-Curtis) distance measures were calculated on a matrix of 13 jellyfish species in 40 full-water-column samples. To adjust for a broad range of very abundant to rare species, abundance data were normalized using $[\log 10(Y+0.001)+3]$. The use of $(Y+0.001)+3$ rather than $(Y+1)$ helped prevent distorting the relationship between zeros and small non-zero values in the dataset [31]. The stability of the final configuration was evaluated using a Monte Carlo Stress Test computing Mather's [32] scaling and Kruskal's [33] stress formula one, scaled from $0-100$ as $S_{R}=100 \sqrt{ } S$. Following ordination, the data cloud was rigidly rotated to load the maximum variance in taxonomic composition along Axis 1 . This rigid rotation did not affect the geometry of points in the ordination space or the total variance explained by the ordination, but simply realigned the ordination points such that the greatest dissimilarity in community structure among samples lay along the first axis [31]. To explore drivers of community variance, Pearson correlations were calculated between the axis values for species abundances and environmental variables: year; month; station (coded 1-4 from north to south); maximum, minimum, average, and values at $2-\mathrm{m}$ and $30-\mathrm{m}$ depths for temperature, salinity, dissolved oxygen, density, and fluorescence. In addition to the ordination, a Permutational multivariate analysis of variance (PerMANOVA) with pairwise comparisons ([34]) was run in PC-ORD ${ }^{\mathrm{TM}}$ using Sørensen (Bray-Curtis) distance measures to test for differences between station pairs [31].

\section{Results}

\subsection{Environmental Properties}

Hood Canal was stratified from June to September in both years, typically with strong thermoclines and pycnoclines in the upper $10 \mathrm{~m}$ of the water column (Figure 2a). Overall, temperatures ranged from 8.2 to $21.5^{\circ} \mathrm{C}$ and were $0.5-1.0^{\circ} \mathrm{C}$ cooler in 2012 than 2013. Surface temperatures were often highest at $\mathrm{DB}$, but showed no consistent pattern among the other stations. Deep water was typically $8-10^{\circ} \mathrm{C}$ until intrusion of dense, warmer ocean water or wind-mixing warmed deep waters in fall. Deep waters were typically warmer at the northern stations than in the south in summer and particularly following the deep-water intrusions, by up to $1.3{ }^{\circ} \mathrm{C}$ difference in October 2012.

Oxygen concentrations showed a typical seasonal cycle of oxygen drawdown through summer, with lowest oxygen at the southern stations (Figure 2b). Oxygen mostly remained well above $4 \mathrm{mg} \mathrm{L}^{-1}$ at the two northern stations, but in late summer, much of the water column was below $4 \mathrm{mg} \mathrm{L}^{-1}$ at the southern stations. Oxygen did not drop to hypoxic levels in 2012 except at Union in October. However, 
hypoxia was present at Union and Hoodsport in August through October 2013. In 2013, bottom-water DO at Union reached a minimum of $1.7 \mathrm{mg} \mathrm{DO} \mathrm{L}^{-1}$ at $75 \mathrm{~m}$ depth in August, $1.8 \mathrm{mg} \mathrm{DO} \mathrm{L}^{-1}$ at $74 \mathrm{~m}$ depth in September, and was displaced upwards to a near-surface oxygen minimum layer in October (1.6-2.0 $\mathrm{mg} \mathrm{DO} \mathrm{L}^{-1}$ at 5-16 m).

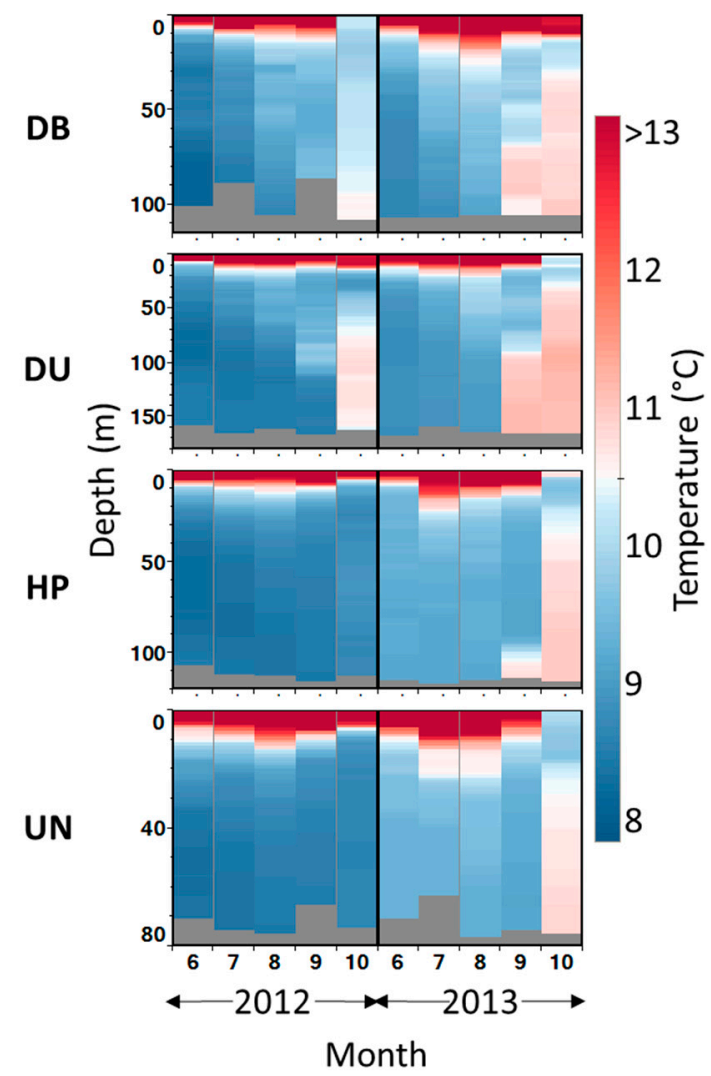

(a)

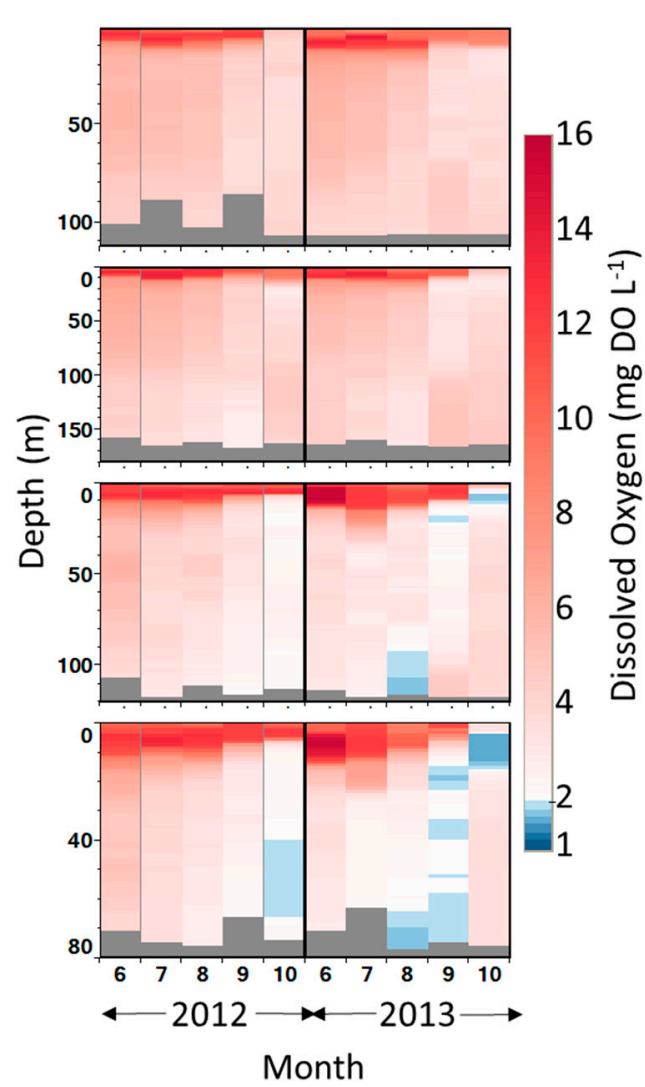

(b)

Figure 2. Seasonal profiles of $(\mathbf{a})$ temperature $\left({ }^{\circ} \mathrm{C}\right)$ and $(\mathbf{b})$ dissolved oxygen concentrations $\left(\mathrm{mg} \mathrm{L}^{-1}\right)$ at Dabob (DB), Duckabush (DU), Hoodsport (HP), and Union (UN). Red indicates higher temperatures and dissolved oxygen concentrations, while blue indicates lower temperatures and dissolved oxygen concentrations $\leq 2.0 \mathrm{mg} \mathrm{L}^{-1}$.

\subsection{Species Composition}

Overall, fifteen taxa were identified in Hood Canal, several of which are known to be cruising or ambush predators: three scyphozoans, eleven hydrozoans (including two siphonophores), and one ctenophore (Table 1). The dominant species in the mesoplankton size range was Muggiaea atlantica-a colonial calycophoran siphonophore averaging $\sim 5.4 \mathrm{~mm}$ nectophore bell height, with feeding component densities (nectophores, eudoxids with bracts, and separated bracts) orders of magnitude higher than all other species (peak densities $>1800 \mathrm{Ind}^{-3}$, Figure 3a; Table 1). Aglantha digitale and Clytia gregaria, both averaging $>4 \mathrm{~mm}$, were the next most abundant species with maximum densities of $38 \mathrm{Ind} \mathrm{m}^{-3}$ and $18 \mathrm{Ind} \mathrm{m}^{-3}$, respectively (Figure $3 \mathrm{~b}$; Table 1). M. atlantica dominated the southern stations, especially during mid-summer to fall, whereas A. digitale dominated the northern stations in early summer. All other species were relatively rare at $<5 \mathrm{Ind}^{-3}$ (Figure $3 \mathrm{c}, \mathrm{d}$ ). 
(a)

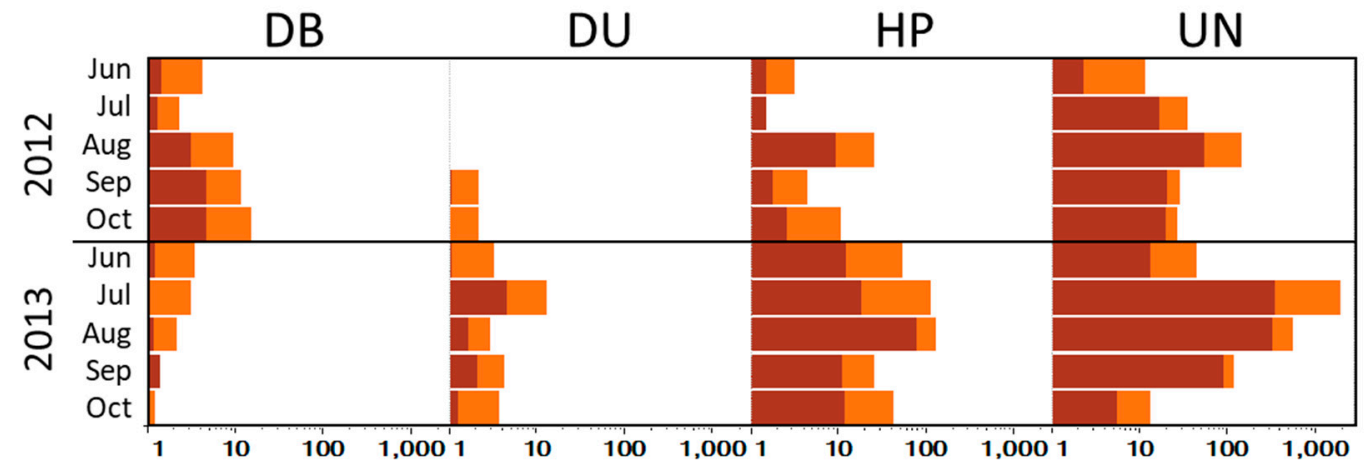

(b)

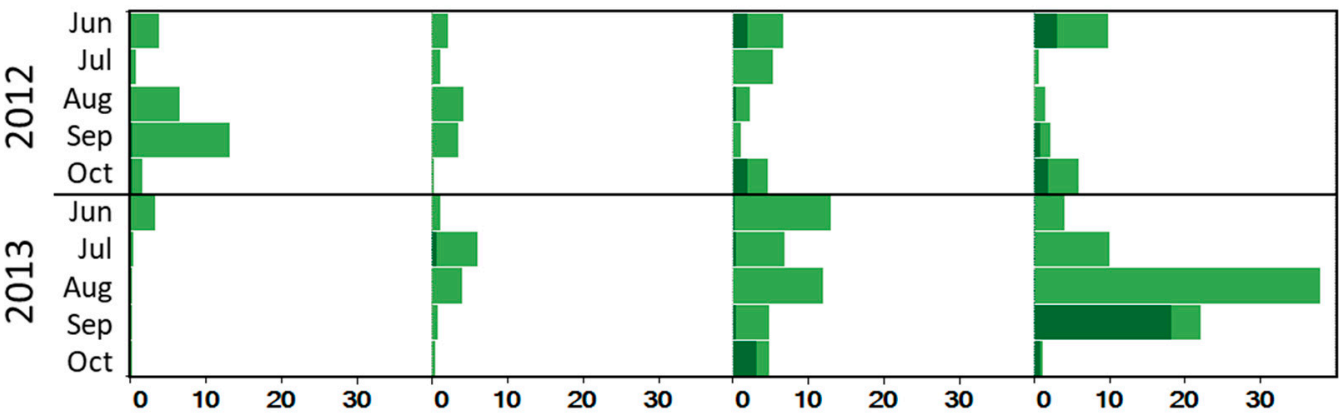

(c)

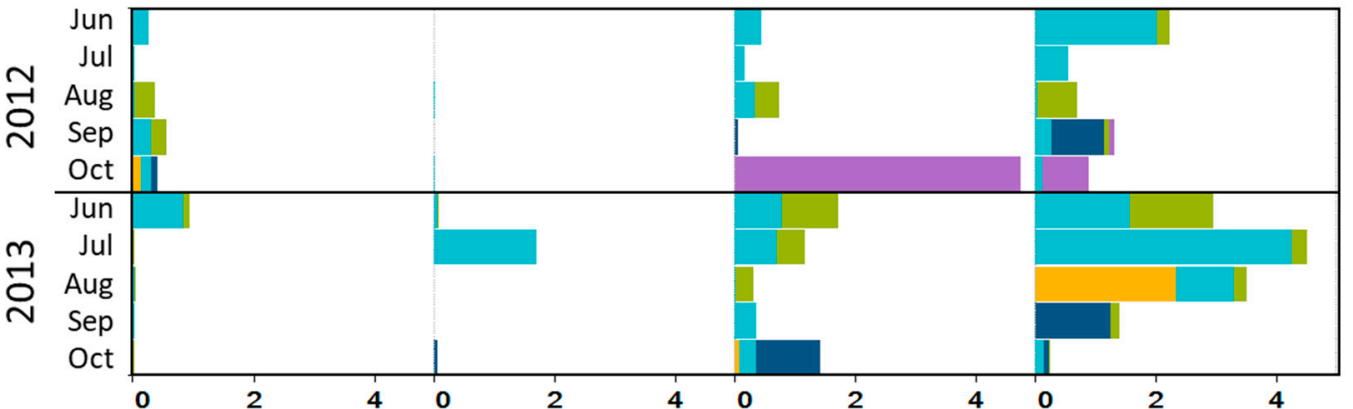

(d)

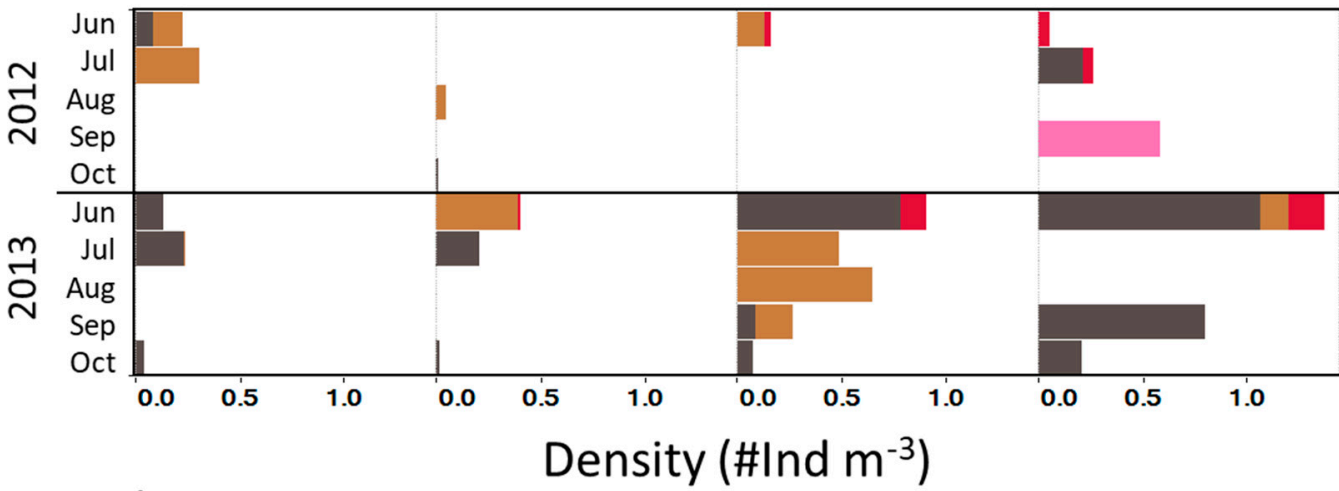

\section{Genus species}

Muggiaea atlantica - eudoxid/bract

Muggiaea atlantica - nectophore

Aglantha digitale

Clytia gregaria

Obelia sp.

Leuckartiara sp.

Euphysa sp.

Proboscidactyla flavicirrata

Geomackiea zephyrolata

Figure 3. Temporal and spatial patterns in species abundances (Ind $\mathrm{m}^{-3}$ ) of (a) dominant, Muggiaea atlantica, (b) more abundant, (c) rare, and (d) very rare jellyfish at four stations in Hood Canal. $M$. atlantica's individual predatory gastrozooids are separated by color (nectophores versus eudoxids/bracts). Species with less than 4 occurrences were not plotted. Note different $x$-axis scales and log-scaling of (a). 
Table 1. Average diameter (D), bell height $(\mathrm{H})$, number measured $(n)$, and predation method of megaplankton and mesoplankton species collected from Hood Canal. Note only sizes of mesoplanktonic species are given.

\begin{tabular}{|c|c|c|c|c|c|}
\hline $\begin{array}{l}\text { Class/Order } \\
\text { Genus species }\end{array}$ & Life History Stage & $\mathbf{n}$ & Avg D (mm) & Avg H (mm) & Predation Method \\
\hline \multicolumn{6}{|l|}{ Scyphozoa } \\
\hline Aurelia aurita & Medusa & - & - & - & Cruising $\star$ \\
\hline Cyanea capillata & Medusa & - & - & - & Cruising $\star$ \\
\hline $\begin{array}{l}\text { Phacellophora } \\
\text { camtschatica } \\
\text { Hydrozoa }\end{array}$ & Medusa & - & - & - & Cruising $\star$ \\
\hline Aequorea victoria & Medusa & 19 & 36.63 & 7.68 & Cruising $\star$ \\
\hline Aglantha digitale & Medusa & 1080 & 2.81 & 4.36 & Ambush $\star \star$ \\
\hline Clytia gregaria & Medusa & 358 & 4.92 & 1.82 & Cruising $\star \star$ \\
\hline Euphysa sp. & Medusa & 146 & 0.79 & 1 & - \\
\hline $\begin{array}{l}\text { Geomackiea } \\
\text { zephyrolata }\end{array}$ & Medusa & 25 & 1.5 & 1.49 & - \\
\hline Leuckartiara sp. & Medusa & 117 & 2.26 & 2.76 & Ambush $\star \star$ \\
\hline Obelia sp. & Medusa & 40 & 0.72 & 0.32 & - \\
\hline $\begin{array}{l}\text { Proboscidactyla } \\
\text { flavicirrata }\end{array}$ & Medusa & 227 & 3.36 & 2.23 & - \\
\hline $\begin{array}{l}\text { Rathkea sp. } \\
\text { Siphonophora }\end{array}$ & Medusa & 79 & 0.72 & 0.59 & - \\
\hline \multirow[t]{4}{*}{ Muggiaea atlantica } & Nectophore & 984 & 2.06 & 5.42 & Ambush $\star \star$ \\
\hline & Bract & 891 & 0.99 & 1.33 & \\
\hline & Eudoxid & 541 & 0.89 & 2.22 & \\
\hline & Gonophore & 1738 & 0.96 & 1.65 & \\
\hline $\begin{array}{l}\text { Nanomia bijuga } \\
\text { Ctenophora }\end{array}$ & Nectophore & 75 & 2.85 & 3.15 & Ambush $\star \star$ \\
\hline Pleurobrachia bachei & Adult & 95 & 3.88 & 4.16 & Ambush $\star \star$ \\
\hline
\end{tabular}

Predation methods based on $\star$ (Purcell and Arai 2001) and $\star \star$ (Colin et al. 2003).

The seasonal timing of peak abundance varied by species, year, and station, with overall higher abundances at Union, and peak abundances occurring earlier in 2013 than in 2012 (Figure 4). Total mesoplankton jellyfish abundances were significantly higher in 2013 than 2012 (Figure 4), which was especially noticeable in the ten-fold increase of M. atlantica gastrozooids, A. digitale, and C. gregaria (Figure 3a,b). Several of the rarer taxa, including Leuckartiara sp., Proboscidactyla flavicirrata, and the physonect siphonophore Nanomia bijuga occurred most frequently in early summer at the southern stations and were more common in 2013. Euphysa sp. was found at the southern stations but only during the autumn months, whereas Obelia sp. and Rathkea sp. were only observed at southern stations in Fall 2012 (Figure 3c,d). An especially rare jellyfish, Geomackiea zephyrolata-described by Mills [35]—-was only collected in three net tows, primarily at Union in August 2013 (Figure 3c). Pleurobrachia bachei, the only ctenophore in our collections, was observed at all stations, chiefly at Hoodsport and Union early summer and late fall in 2013; they were largely absent in 2012 (Figure 3d).

Aequorea victoria, the largest hydrozoan in Hood Canal, was rarely seen in the mesoplankton nets except in early summer at Hoodsport and Union (Figure 3d) yet dominated the abundance of megaplankton jellyfish collected by trawls in June and July of both years (Figure S1). The large scyphozoans, Aurelia labiata and Phacellophora camtschatica, were not collected in mesoplankton net tows, and only a few small Cyanea capillata were found. However, these taxa were frequently observed in the mid-water trawls. C. capillata was the only ubiquitous species, observed at all stations over the full sampling period, and typically dominated the megaplankton jellyfish biomass except in August when $P$. camtschatica dominated. A. labiata was not common, although it can be highly abundant throughout summer in other regions of Puget Sound, particularly in sheltered embayments [36,37]. 


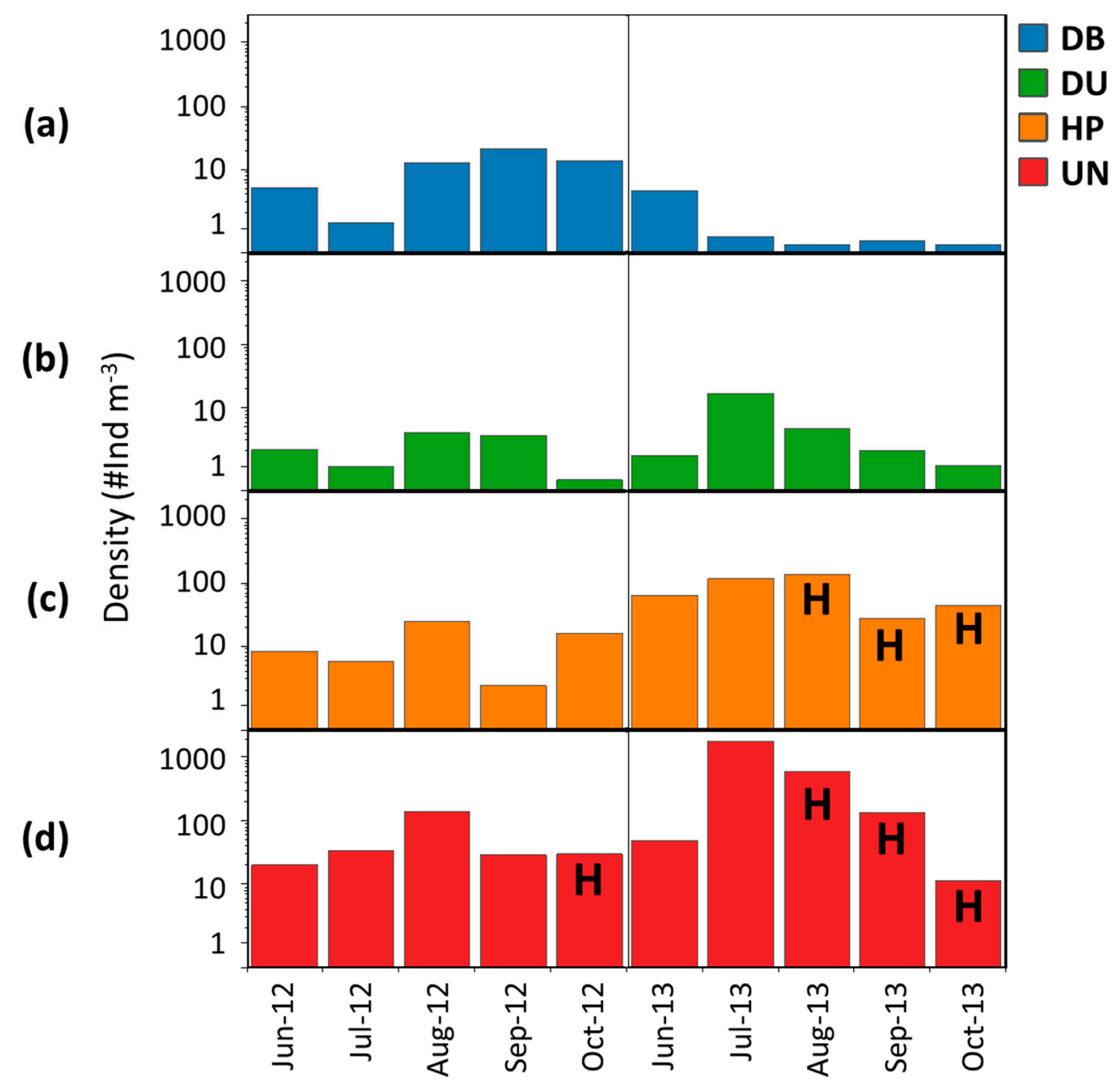

Figure 4. Total mesoplankton jellyfish abundances $\left(\mathrm{Ind}^{-3}\right.$ ) at four stations in Hood Canal (a) Dabob, (b) Duckabush, (c) Hoodsport, and (d) Union during June through August 2012 and 2013, colored by station. ' $\mathrm{H}$ ' indicates stations with bottom-water or mid-layer hypoxia $\left(\leq 2.0 \mathrm{mg} \mathrm{DO} \mathrm{L}^{-1}\right)$.

\subsection{NMS Ordinations}

Nonmetric Multidimensional Scaling (NMS) ordination resulted in a 3-dimensional solution with a final stress of 11.7 and a cumulative variance explained of $89 \%$. After final rotation, variability along Axis 1 explained $61 \%$ of the variance in community structure, with Axis 2 and 3 carrying only $15 \%$ and $14 \%$, respectively. The ordination showed clear distinction in community structure at the southern (Hoodsport and Union) versus northern (Dabob and Duckabush) stations along Axis 1 in both years (Table 2; Figure 5a), with the largest separation between Union (positive on Axis 1) and Duckabush (most negative on Axis 1). The community at Hoodsport was more similar to Union; the community at Dabob Bay was more similar to Duckabush. Patterns among months were not well defined (Figure $5 b$ ). Minimum dissolved oxygen levels were also oriented positively along Axis 1 (Figure $5 \mathrm{c}$ ), likely because of the position of the hypoxic locations of Hoodsport and Union on the axis. Communities were less tightly clustered (more dissimilar) in 2012 than 2013. 
(a)

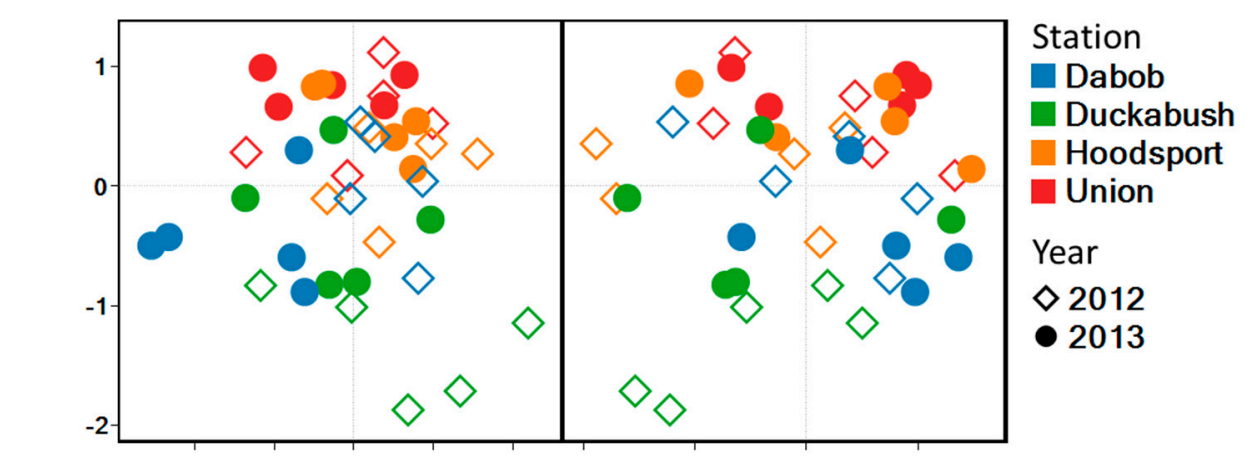

(b)

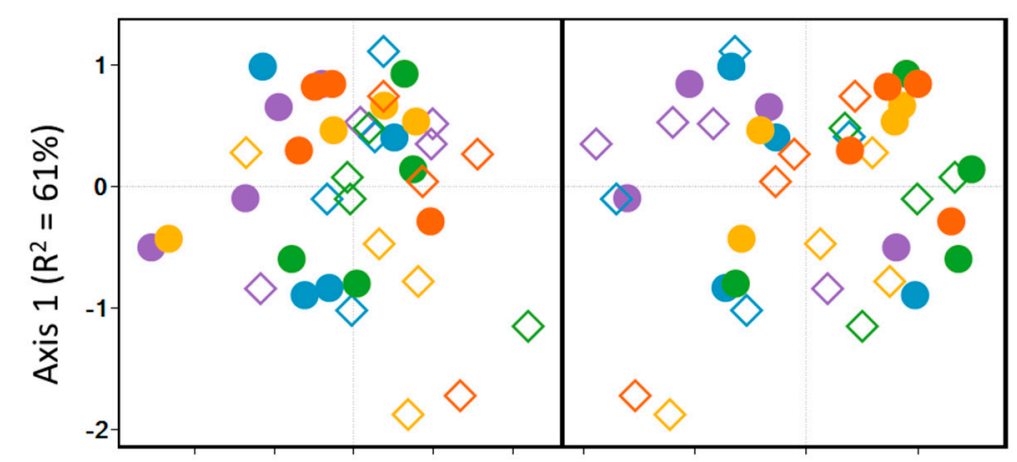

\section{Month}

June

July

August

- September

October

(c)

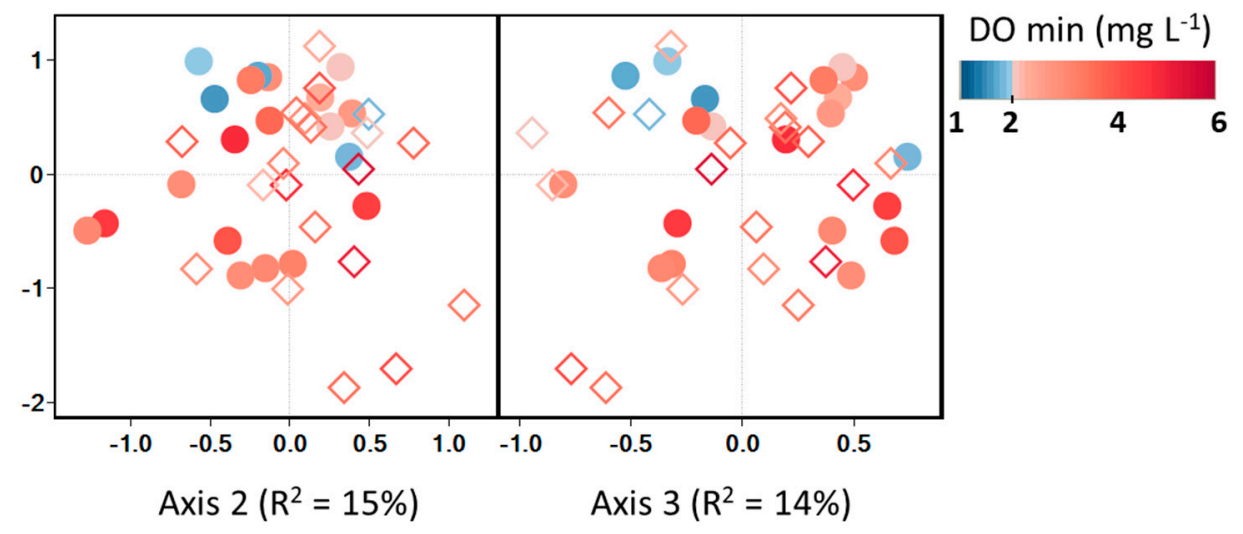

Figure 5. Nonmetric Multidimensional Scaling ordination of mesoplankton jellyfish composition in Hood Canal showing Axis 1 vs. Axis 2 (left panels) and Axis 1 vs. Axis 3 (right panels). Symbols are coded by year (2012 as open diamonds; 2013 as closed circles) and colored by (a) station, (b) month, or (c) minimum dissolved oxygen concentration within the water column.

Species most strongly associated with Axis 1 were M. atlantica $(r=0.87)$, C. gregaria $(r=0.81)$, and P. flavicirrata $(\mathrm{r}=0.67)$ (Table 2$)$. All species except $C$. capillata were positively associated with Axis 1 (i.e., generally more abundant in samples toward the top of the ordination). A. digitale and P. bachei were weakly associated with Axis $2(r=0.59$ and $r=-0.56$, respectively), and Leuckartiara sp. positively correlated with Axis $3(r=0.62)$. Few environmental variables correlated with community variance along the axes. The strongest correlation was between Axis 1 and station $(r=0.57)$, capturing the observed separation of the stations; dissolved oxygen at 30-m depth was weakly correlated $(r=-0.49)$ (Table S1). Average temperature through the water column was associated with community variance along Axis $2(\mathrm{r}=-0.60)$, with warmer temperatures in autumn following ocean intrusions (Figure 2). Crustacean prey were also negatively correlated with Axis $2(\mathrm{r}=-0.46)$. No environmental variables correlated well with Axis 3 (Table S1).

PerMANOVA results indicated a significant difference in jellyfish communities among stations $(F=5.79, p=0.0002)$. Pairwise comparisons identified significant differences between all station pairs ( $p<0.011$ in all comparisons) except UN and HP which did not statistically differ $(t=1.14, p=0.28)$. 
Communities also differed between 2012 and $2013(F=3.63, p=0.009)$, and there was a significant interaction between Year and Station $(F=2.15, p=0.02)$.

Table 2. Pearson correlation coefficients $(r)$ and correlations $\left(R^{2}\right)$ between jellyfish and the NMS ordination axes. Taxa strongly correlated with each axis $\left(R^{2}>0.3\right)$ are in bold. Total cumulative $R^{2}$ of the ordination is given as CUM R ${ }^{2}$.

\begin{tabular}{|c|c|c|c|c|c|c|}
\hline \multirow[t]{2}{*}{$C_{U M} R^{2}=0.89$} & \multicolumn{2}{|c|}{$\begin{array}{c}\text { Axis } 1 \\
\left(R^{2}=0.61\right)\end{array}$} & \multicolumn{2}{|c|}{$\begin{array}{c}\text { Axis } 2 \\
\left(R^{2}=0.15\right)\end{array}$} & \multicolumn{2}{|c|}{$\begin{array}{c}\text { Axis 3 } \\
\left(R^{2}=0.14\right)\end{array}$} \\
\hline & $\mathbf{r}$ & $\mathbf{R}^{2}$ & $\mathbf{r}$ & $\mathbf{R}^{2}$ & $\mathbf{r}$ & $\mathbf{R}^{2}$ \\
\hline Aequorea victoria & 0.3 & 0.09 & 0 & 0 & 0.27 & 0.08 \\
\hline Aglantha digitale & 0.41 & 0.17 & 0.59 & 0.35 & 0.08 & 0.01 \\
\hline Clytia gregaria & 0.81 & 0.65 & 0.12 & 0.01 & -0.3 & 0.09 \\
\hline Cyanea capillata & -0.16 & 0.03 & 0.37 & 0.14 & -0.18 & 0.03 \\
\hline Euphysa sp. & 0.39 & 0.16 & -0.23 & 0.05 & -0.47 & 0.22 \\
\hline Geomackiea zephyrolata & 0.29 & 0.09 & 0.06 & 0 & -0.06 & 0 \\
\hline Leuckartiara sp. & 0.52 & 0.27 & -0.1 & 0.01 & 0.62 & 0.38 \\
\hline Muggiaea atlantica & 0.87 & 0.75 & -0.06 & 0 & 0.25 & 0.06 \\
\hline Nanomia bijuga & 0.01 & 0 & 0.43 & 0.18 & 0.35 & 0.12 \\
\hline Obelia sp. & 0.22 & 0.05 & 0.24 & 0.06 & -0.37 & 0.14 \\
\hline Pleurobrachia bachei & 0.36 & 0.13 & -0.56 & 0.32 & -0.03 & 0 \\
\hline Proboscidactyla flavicirrata & 0.67 & 0.44 & 0.22 & 0.05 & 0.46 & 0.22 \\
\hline Rathkea sp. & 0.24 & 0.06 & 0.06 & 0 & -0.11 & 0.01 \\
\hline
\end{tabular}

\subsection{Species Diversity}

Species richness, evenness, and diversity of mesoplankton jellyfish varied temporally and among stations (Figure 6). Between one and eight species were collected per sampling event; the maximum number at Union and the minimum at Duckabush, where at times, only 1-2 species were found. At the southern stations ( $\mathrm{UN}$ and $\mathrm{HP}$ ), the three metrics $\left(\mathrm{S}, \mathrm{E}_{\mathrm{H}}\right.$, and $\left.\mathrm{H}\right)$ approximately tracked each other over time, whereas the two northern stations (DB and DU) were more varied, particularly in diversity. In 2012, DB was similar to UN and HP in species richness yet diverged in evenness and diversity over the season. In 2013, there was a clearer separation of the two northern from the two southern stations. Species richness declined at both northern stations, but was more stable at the southern stations, over the season before all increased slightly in October (Figure 6a). Conversely, species evenness and diversity were higher at the northern stations in 2013, and lower at the southern stations (Figure 6b,c), especially in July and August when M. atlantica was particularly abundant in the south.

\subsection{Vertical Distributions}

Daytime vertical distributions of jellyfish examined at Union during hypoxia showed decreased abundances with depth, specifically for the dominant taxa M. atlantica, C. gregaria, and A. digitale (Figure 7). Overall, $>80 \%$ of the community occupied the top $20 \mathrm{~m}$ of the water column (Figure S2). This was true even in October when a strong oxygen minimum layer was present near surface at 5-16 m depth, which was sampled by a net towed over 6-10 $\mathrm{m}$ depths (Figure 7c and Figure S2b). Several jellyfish species were more abundant in the most hypoxic water layer $(6-10 \mathrm{~m})$ than above or below. These included the hydrozoans Euphysa sp., Rathkea sp., Leuckartiara sp., and ctenophore $P$. bachei. Another hydrozoan, P. flavicirrata, was also relatively abundant in the hypoxic layer, although less so than in the 10-20 m layer (Figure 7c). A. digitale and Rathkea sp. were more evenly distributed throughout the water column than most taxa (Figure 3). The rare G. zephyrolata was only present below $20 \mathrm{~m}$, whereas Obelia sp. were only sampled in the top $10 \mathrm{~m}$ (Figure 7). 
(a)

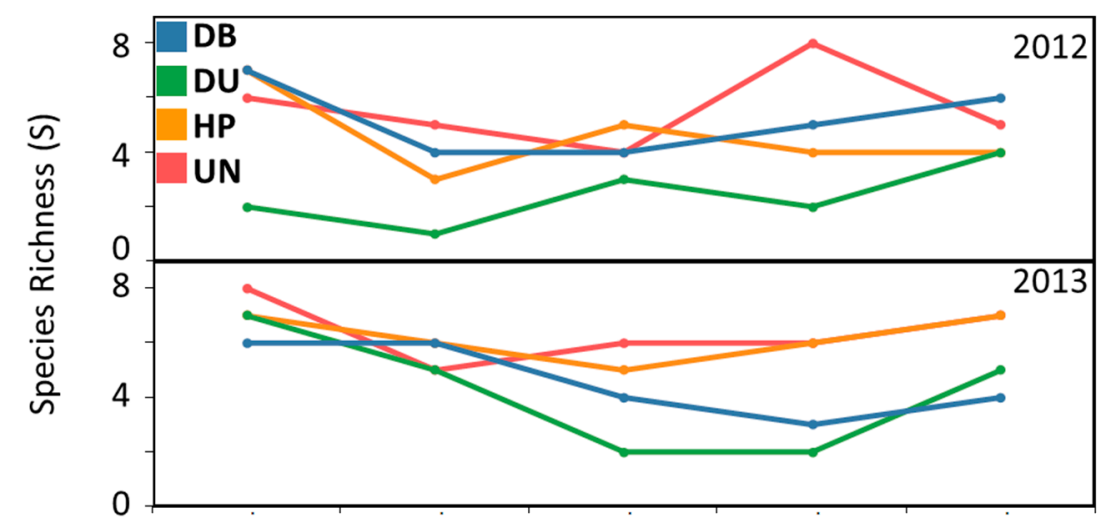

(b)

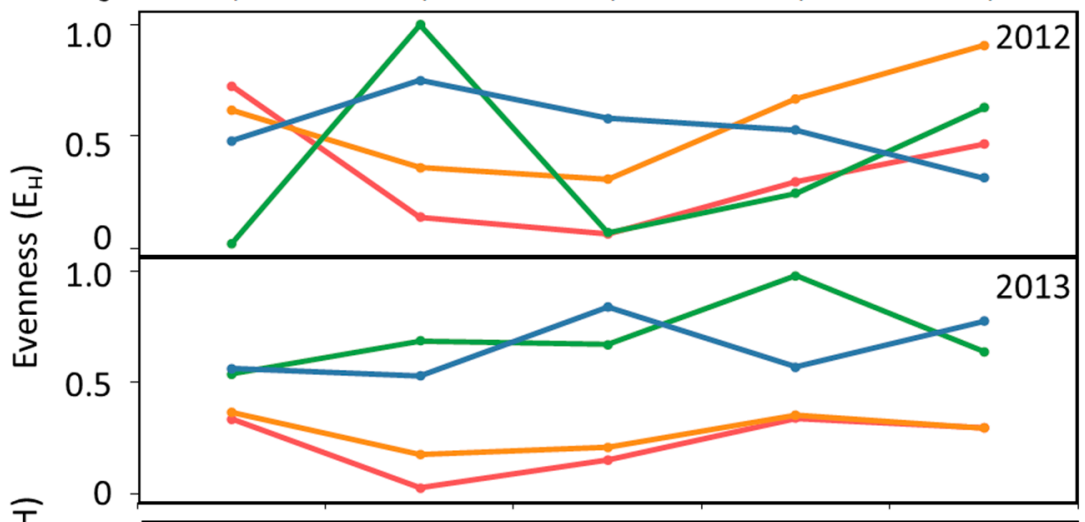

(c)

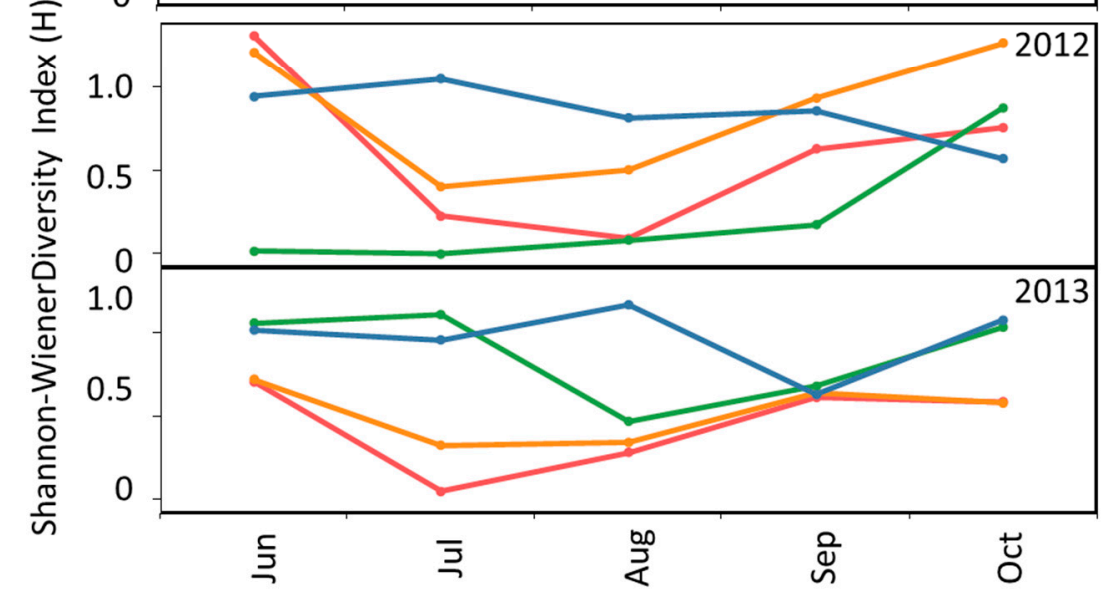

Figure 6. Seasonal changes in (a) species richness, (b) species evenness, and (c) Shannon-Wiener Diversity Index from the four stations Dabob (DB), Duckabush (DU), Hoodsport (HP), and Union (UN) in 2012 and 2013.

The most abundant potential prey collected were copepods, early life stages of euphausiids (mainly eggs and nauplii), barnacle larvae, and ostracods. Vertical distributions of prey closely matched the jellyfish distributions in August and September when both were most abundant in the surface layer and declined with depth (Figure S3a,b), a pattern that was particularly pronounced in September when barnacles and euphausiids were highly abundant near surface. In October, prey distribution did not match jellyfish as well-prey were concentrated deeper, in the 6-10 m hypoxic layer and in the 10-20 m depth layer (Figure S3c). Majority of prey were less abundant in deep hypoxic water in August and September, but most abundant in the mid-water hypoxic layer in October. Notably high abundances of copepods were aggregated in the hypoxic 6-10 m layer in October. Harpacticoid copepods occupied mid-depth layers each month. Ostracods were consistently found at deeper depths, regardless of oxygen conditions. 

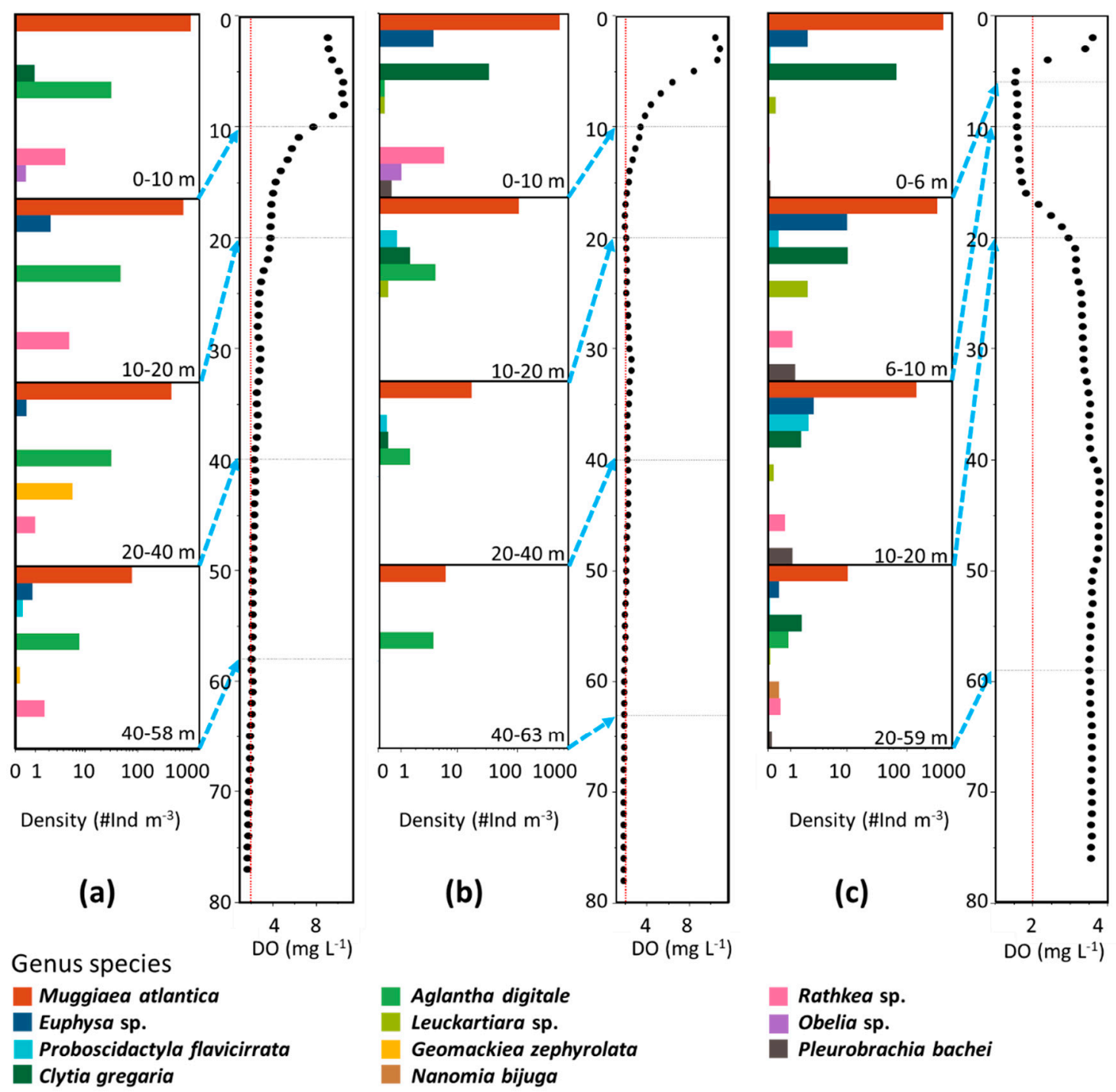

Figure 7. Daytime vertical distributions of mesoplankton jellyfish $\left(\mathrm{Ind}^{-3}\right)$ during hypoxic events at Union in (a) August, (b) September, and (c) October 2013 with corresponding CTD profiles of dissolved oxygen $\left(\mathrm{mg} \mathrm{L}^{-1}\right)$. Depth range sampled by each net is indicated in panels using horizontal grey lines and blue dashed arrows. Vertical red lines indicate $2 \mathrm{mg} \mathrm{L}^{-1}$ dissolved oxygen. Note that hypoxic water was present in deep water in August and September, but near surface in October. Note the log scaling of densities.

\section{Discussion}

\subsection{Trophic Roles}

Jellyfish can be voracious predators capable of asserting significant predation pressure on plankton communities, particularly when in high abundance. Most of the jellyfish species identified in Hood Canal were rare, with densities $<5 \mathrm{Ind} \mathrm{m}^{-3}$, but the dominant species, Aequorea victoria and Muggiaea atlantica, likely exerted a strong influence on their prey during their peak abundances.

M. atlantica are complex siphonophores existing either as colonies comprised of several zooid components, including a nectophore and multiple eudoxids, or as separated free-swimming eudoxids [27,38]. M. atlantica feed primarily on copepods, though other prey are consumed [39]. Despite the diminutive size of individual components, a colony with extended tentacles can cover a broad volume; a single nectophore with several gastrozooids consumes $\sim 5-10$ prey per day during non-growth stages; while growing, this rate can more than double, especially when prey are abundant [27]. In 2013, 
M. atlantica abundance (nectophores plus separated bracts) increased from 47 to 1859 Ind $\mathrm{m}^{-3}$ between our June and July sampling at Union, indicating a strong growth phase which was also evident from the high densities $\left(1647 \mathrm{~m}^{-3}\right)$ of reproductive gonophores. Based on their July nectophore densities and colony feeding rates from Purcell [27], their potential predation could have reached $\sim 3400$ prey $\mathrm{m}^{-3} \mathrm{~d}^{-1}$. Copepod density was $\sim 5000 \mathrm{~m}^{-3}$ at Union in July 2013 , which declined to $<1000 \mathrm{~m}^{-3}$ by August (data shown in [40]) potentially indicating the effect of the siphonophores' predation. When oxygen is low, jellyfish may have even higher predatory potential if escape abilities of their prey are diminished relative to jellyfish swimming and feeding behaviors [14].

In addition to copepods, jellyfish can put significant predation pressure on gelatinous and other soft-bodied taxa. Studies have reported that Aequorea and Aurelia can dramatically reduce fish eggs and larvae [41,42] and larvaceans [15]. Intraguild predation is also common. Predation of P. camtschatica on A. labiata has been reported [37], as has predation of A. victoria on M. atlantica, a favorite prey item [43,44]. A. victoria has also been known to prey on the ctenophore Pleurobrachia bachei and more than nine other hydrozoans, including Aglantha digitale and the physonect Nanomia bijuga [45]. In Hood Canal, A. victoria occupied Union and Hoodsport in very high numbers ( $>1000$ Ind over a $\sim 1.3 \mathrm{~km}$ tow) during June of both years, but diminished by July, around the time when the M. atlantica population dramatically increased. The reasons for the seasonal decline in A. victoria are unclear, but the result may have been released predation pressure on M. atlantica, allowing their bloom. The co-occurrence of taxa raises the question of whether their interactions release predation pressure on crustacean zooplankton through intraguild predation, or whether they primarily compete for mesozooplankton prey.

\subsection{Vertical Distributions}

Jellyfish vary in their hypoxia tolerance $[10,11]$, and some species may even avoid very low oxygen levels [46]. Of species studied in Puget Sound, M. atlantica has the lowest critical oxygen partial pressure $\left(\mathrm{P}_{\text {crit }} \sim 0.2 \mathrm{mg} \mathrm{L}^{-1}\right.$ at $10^{\circ} \mathrm{C}, 30 \mathrm{psu}$ ), indicating high hypoxia tolerance, whereas Euphysa flammea has the highest $\mathrm{P}_{\text {crit }}\left(\sim 1.8 \mathrm{mg} \mathrm{L}^{-1}\right)$ [11]. In our study, daytime vertical distributions did not reflect those tolerances. $M$. atlantica primarily occupied upper layers of the water column, even when oxygen through the full water column was above their $\mathrm{P}_{\text {crit }}$ level. Euphysa sp. was more patchily distributed but did not appear to avoid hypoxic water, and was in highest abundance in the most hypoxic layer in October although existing oxygen levels were below their $\mathrm{P}_{\text {crit }}$. Additionally, that M. atlantica was most abundant near surface during daytime suggests they were not performing diel vertical migration (DVM), contrary to reports that many jellyfish do, including other species of Muggiaea [47-49].

It is likely the jellyfish distributions reflected their prey's vertical distributions rather than oxygen. Crustacean prey taxa which also commonly conduct DVM were dense near surface in the daytime when deep water was hypoxic. This contrast from expected daytime distributions is perplexing as it suggests the zooplankton sensed and avoided hypoxia, but in October, they were most abundant in the near-surface hypoxic layer where oxygen was $1.5-1.8 \mathrm{mg} \mathrm{L}^{-1}$. Some reports of geographic differences in copepod response imply that only populations that inhabit historically hypoxic regions will move to avoid hypoxia [50], but Hood Canal has been hypoxic for hundreds of years [51]. There are wide differences in behavioral response to hypoxia among species in Hood Canal [52], consequently more specific taxonomic information could help explain patterns observed in this study.

Species differences in behavior can lead to changes in vertical overlap and encounters between predators and their prey, as well as changes in prey capture success. In Chesapeake Bay, overlap between ctenophores and their prey decreases as copepods and fish larvae move up to avoid hypoxic depths where ctenophores remain within [46,53]. Simultaneously, overlap with the sea nettle Chrysaora increases as it moved up with its prey, compressing into upper layers and resulting in higher encounter rates [46]. For taxa which remain in hypoxic water, differential susceptibility to hypoxia can alter encounter outcomes. The medusae Aurelia aurita [42] and Chrysaora quinquecirrha [13], and the 
ctenophore Mnemiopsis leidyi [53], all increase predation rates on fish larvae and zooplankton under low oxygen as their prey's escape abilities decline.

\subsection{Abundance and Community Patterns}

The pattern of higher jellyfish abundances and species richness at the southern stations indicate that those locations may be reproduction or grazing hotspots for gelatinous zooplankton. Notably, every species collected was more abundant in southern Hood Canal, and two (Obelia and Rathkea) were exclusively found there. Species distributions were likely influenced by the distance from the canal's inlet, hydrographic conditions, and the degree of anthropogenic disturbance to the ecosystem, all of which differ along the axis of the canal. That Dabob and Duckabush were more variable in species composition, as shown by the NMS ordination, but lower in species richness, may indicate that advective exchange with water outside of the canal is important. One study regarding circulation and the swimming behavior of Cyanea capillata in Hood Canal indicated that southern Hood Canal may be a sink for the large medusae [54]. Another trawl study of jellyfish found that large scyphozoan medusae are less abundant north of Puget Sound [55]. Moreover, forage fish and jellyfish showed opposite gradients in distributions, suggesting competitive or trophic interactions.

For the most part, the environmental metrics that we measured did not statistically correlate with community structure. Although the southern communities separated from those in the north, average temperature (primarily reflecting sub-thermocline temperature) was the only environmental correlate with NMS axes. Oxygen did not emerge as an important correlate with the ordination axes. The more hypoxic stations clearly supported a higher variety of species and higher abundances, but that was true even when oxygen was relatively high; most species were less abundant during hypoxic months. Perhaps hypoxia primes the system for successful jellyfish populations the following year, e.g., by reducing competition over winter, or that other conditions associated with the development of hypoxia also promote jellyfish, e.g., sluggish circulation. Overall, hypoxia did not seem to have a detrimental effect on gelatinous zooplankton, and could have been beneficial through food web processes, likely with influences on resident fish and zooplankton communities.

Supplementary Materials: The following are available online at http://www.mdpi.com/1424-2818/12/2/53/s1: Table S1: Pearson correlations between environmental variables and NMS ordination axes. Figure S1: Midwater trawl megaplankton jellyfish distributions, Figure S2: Vertical distributions of mesoplankton jellyfish and crustacean prey taxa, Figure S3: Daytime vertical distribution of crustacean prey taxa.

Author Contributions: Conceptualization, B.H. and J.E.K.; Methodology, B.H. and J.E.K.; Investigation, B.H. and J.E.K.; Formal analysis, B.H. and J.E.K.; Data Curation, B.H.; Writing-Original Draft Preparation, B.H.; Writing-Review \& Editing, B.H. and J.E.K.; Project Administration, J.E.K.; Funding Acquisition, J.E.K. All authors have read and agreed to the published version of the manuscript.

Funding: This research was supported by National Science Foundation grants \#OCE-1154648 and OCE-1657992.

Acknowledgments: We thank Claudia Mills for assistance with species identification; the UW Marine Chemistry Laboratory for oxygen titrations; T. Essington, P. Moriarty, and M. Sato for mid-water trawl data; Captain R. McQuin, L. Tuttle, the ship crew, and numerous volunteers who assisted with sampling on the R/V Clifford Barnes. This study comprised the thesis research of B. Herrmann as partial fulfillment of a B.S. degree in Oceanography at the University of Washington.

Conflicts of Interest: The authors declare no conflict of interest. The funders had no role in the design of the study; in the collection, analyses, or interpretation of data; in the writing of the manuscript, or in the decision to publish the results.

\section{References}

1. Larson, R.J.; Madin, L.P.; Harbison, G.R. In situ observations of deepwater medusae in the genus Deepstaria, with a description of D. reticulum, sp. nov. J. Mar. Biol. Assoc. UK 1988, 68, 689-699. [CrossRef]

2. Pitt, K.A.; Duarte, C.M.; Lucas, C.H.; Sutherland, K.R.; Condon, R.H.; Mianzan, H.; Purcell, J.E.; Robinson, K.L.; Uye, S. Jellyfish body plans provide allometric advantages beyond low carbon content. PLoS ONE 2013, 8, e72683. [CrossRef] [PubMed] 
3. Mills, C.E.; Marques, A.C.; Migotto, A.E.; Calder, D.R.; Hand, C. Hydrozoa: Polyps, Hydromedusae, and Siphonophora. In The Light and Smith Manual: Intertidal Invertebrates from Central California to Oregon, 4th ed.; Carlton, J.T., Ed.; University of California Press: Berkeley, CA, USA, 2007; pp. 118-188. ISBN 978-0520239395.

4. Agassiz, E.C.C.; Agassiz, A. Seaside Studies in Natural History: Marine Animals of Massachusetts Bay, Radiates, 1st ed.; Ticknor and Fields: Boston, MA, USA, 1865; p. 39.

5. Parsons, T.R.; Lalli, C.M. Jellyfish population explosions: Revisiting a hypothesis of possible causes. La Mer 2002, 40, 111-121.

6. Greve, W. The 1989 German Bight invasion of Muggiaea atlantica. ICES J. Mar. Sci. 1994, 51, 355-358. [CrossRef]

7. Uye, S. Human forcing of the copepod-fish-jellyfish triangular trophic relationship. Hydrobiologia 2011, 666, 71-83. [CrossRef]

8. Ishii, H. The influence of environmental changes upon the coastal plankton ecosystems, with special reference to mass occurrence of jellyfish. Bull. Plankt. Soc. Jpn. 2001, 48, 55-61.

9. Purcell, J.E.; Breitburg, D.L.; Decker, M.B.; Graham, W.M.; Youngbluth, M.J.; Raskoff, K.A. Pelagic Cnidarians and Ctenophores in low dissolved oxygen environments: A review. In Coastal Hypoxia: Consequences for Living Resources and Ecosystems; American Geophysical Union: Washington, DC, USA, 2001; pp. 77-100.

10. Thuesen, E.V. Intragel oxygen promotes hypoxia tolerance of scyphomedusae. J. Exp. Biol. 2005, 208, 2475-2482. [CrossRef]

11. Rutherford, L.; Thuesen, E. Metabolic performance and survival of medusae in estuarine hypoxia. Mar. Ecol. Prog. Ser. 2005, 294, 189-200. [CrossRef]

12. Ishii, H.; Ohba, T.; Kobayashi, T. Effects of low dissolved oxygen on planula settlement, polyp growth and asexual reproduction of Aurelia aurita. Plankt. Benthos Res. 2008, 3, 107-113. [CrossRef]

13. Breitburg, D.L. Behavioral response of fish larvae to low dissolved oxygen concentrations in a stratified water column. Mar. Biol. 1994, 120, 615-625. [CrossRef]

14. Breitburg, D.L.; Loher, T.; Pacey, C.A.; Gerstein, A. Varying effects of low dissolved oxygen on trophic interactions in an estuarine food web. Ecol. Monogr. 1997, 67, 489-507. [CrossRef]

15. Purcell, J.E. Predation on zooplankton by large jellyfish, Aurelia labiata, Cyanea capillata and Aequorea aequorea, in Prince William Sound, Alaska. Mar. Ecol. Prog. Ser. 2003, 246, 137-152. [CrossRef]

16. Purcell, J.E.; Arai, M.N. Interactions of pelagic cnidarians and ctenophores with fish: A review. Hydrobiologia 2001, 451, 27-44. [CrossRef]

17. Boero, F.; Bouillon, J.; Gravili, C.; Miglietta, M.; Parsons, T.; Piraino, S. Gelatinous plankton: Irregularities rule the world (sometimes). Mar. Ecol. Prog. Ser. 2008, 356, 299-310. [CrossRef]

18. Orejas, C.; Rossi, S.; Peralba, À.; García, E.; Gili, J.M.; Lippert, H. Feeding ecology and trophic impact of the hydroid Obelia dichotoma in the Kongsfjorden (Spitsbergen, Arctic). Polar Biol. 2013, 36, 61-72. [CrossRef]

19. Pitt, K.A.; Welsh, D.T.; Condon, R.H. Influence of jellyfish blooms on carbon, nitrogen and phosphorus cycling and plankton production. Hydrobiologia 2009, 616, 133-149. [CrossRef]

20. Porter, S.C.; Swanson, T.W. Radiocarbon age constraints on rates of advance and retreat of the Puget Lobe of the Cordilleran Ice Sheet during the last glaciation. Quat. Res. 1998, 50, 205-213. [CrossRef]

21. Gregg, M.C.; Pratt, L.J. Flow and hydraulics near the sill of Hood Canal, a strongly sheared, continuously stratified fjord. J. Phys. Oceanogr. 2010, 40, 1087-1105. [CrossRef]

22. Newton, J.; Bassin, C.; Devol, A.; Kawase, M.; Ruef, W.; Warner, M.; Hannafious, D.; Rose, R. Hypoxia in Hood Canal: An overview of status and contributing factors. In Proceedings of the 2007 Georgia Basin Puget Sound Research Conference, Seattle, WA, USA, 26-29 March 2007.

23. Cannon, G.A. Observations of bottom-water flushing in a fjord-like estuary. Estuar. Coast. Mar. Sci. 1975, 3, 95-102. [CrossRef]

24. Omori, M.; Ikeda, T. Methods in Marine Zooplankton Ecology; John Wiley: New York, NY, USA, 1984; ISBN 0-471-80107-0.

25. Carpenter, J.H. The accuracy of the Winkler Method for dissolved oxygen analysis. Limnol. Oceanogr. 1965, 10, 135-140. [CrossRef]

26. Carpenter, J.H. The Chesapeake Bay Institute technique for the Winkler dissolved oxygen method. Limnol. Oceanogr. 1965, 10, 141-143. [CrossRef]

27. Purcell, J.E. Feeding and growth of the siphonophore Muggiaea atlantica (Cunningham 1893). J. Exp. Mar. Bio. Ecol. 1982, 62, 39-54. [CrossRef] 
28. Shannon, C.E. A mathematical theory of communication. Bell Syst. Tech. J. 1948, 27, 379-423. [CrossRef]

29. Simpson, E.H. Measurement of diversity. Nature 1949, 163, 688. [CrossRef]

30. McCune, B.; Mefford, M.J. PC-ORD. Multivariate Analysis of Ecological Data; Version 7.0 for Windows; Wild Blueberry Media: Corvallis, OR, USA, 2016.

31. McCune, B.; Grace, J.B. Analysis of Ecological Communities; MJM Software Design: Gleneden Beach, OR, USA, 2002; ISBN 0-9721290-0-6.

32. Mather, P.M. Computational Methods of Multivariate Analysis in Physical Geography; John Wiley \& Sons: London, UK, 1976.

33. Kruskal, J.B. Multidimensional scaling by optimizing goodness of fit to a nonmetric hypothesis. Psychometrika 1964, 29, 1-27. [CrossRef]

34. Anderson, M.J. A new method for non-parametric multivariate analysis of variance. Austral Ecol. 2001, 26, $32-46$.

35. Mills, C.E. A new hydrozoan, Geomackiea zephyrolata gen. nov., sp. nov. (Anthomedusae: Pandeidae), from inland marine waters of British Columbia and Washington State. Can. J. Zool. 1985, 63, 2172-2175. [CrossRef]

36. Keister, J.E. Unpublished work. 2020.

37. Towanda, T.; Thuesen, E. Ectosymbiotic behavior of Cancer gracilis and its trophic relationships with its host Phacellophora camtschatica and the parasitoid Hyperia medusarum. Mar. Ecol. Prog. Ser. 2006, 315, 221-236. [CrossRef]

38. Blackett, M.; Licandro, P.; Coombs, S.H.; Lucas, C.H. Long-term variability of the siphonophores Muggiaea atlantica and M. kochi in the Western English Channel. Prog. Oceanogr. 2014, 128, 1-14. [CrossRef]

39. Purcell, J.E. Dietary composition and diel feeding patterns of epipelagic siphonophores. Mar. Biol. 1981, 65, 83-90. [CrossRef]

40. Keister, J.E.; Winans, A.K.; Herrmann, B. Zooplankton community response to seasonal hypoxia: A test of three hypotheses. Diversity 2020, 12, 21. [CrossRef]

41. Purcell, J.E. Predation on fish larvae and eggs by the hydromedusa Aequorea victoria at a herring spawning ground in British Columbia. Can. J. Fish. Aquat. Sci. 1989, 46, 1415-1427. [CrossRef]

42. Shoji, J.; Masuda, R.; Yamashita, Y.; Tanaka, M. Effect of low dissolved oxygen concentrations on behavior and predation rates on red sea bream Pagrus major larvae by the jellyfish Aurelia aurita and by juvenile spanish mackerel Scomberomorus niphonius. Mar. Biol. 2005, 147, 863-868. [CrossRef]

43. Mapstone, G.M. Siphonophore (Cnidaria: Hydrozoa) from Canadian Pacific Waters; NRC Research Press: Ottawa, ON, Canada, 2009; ISBN 90-73239-68-0.

44. Purcell, J.E. Predation by Aequorea victoria on other species of potentially competing pelagic hydrozoans. Mar. Ecol. Prog. Ser. 1991, 72, 255-260.

45. Purcell, J.E. A review of cnidarians and ctenophores feeding on competitors in the plankton. Hydrobiologia 1991, 216, 335-342. [CrossRef]

46. Keister, J.E.; Houde, E.D.; Breitburg, D.L. Effects of bottom-layer hypoxia on abundances and depth distributions of organisms in Patuxent River, Chesapeake Bay. Mar. Ecol. Prog. Ser. 2000, 205, 43-59. [CrossRef]

47. Decker, M.B.; Cieciel, K.; Zavolokin, A.; Lauth, R.; Brodeur, R.D.; Coyle, K.O. Population fluctuations of jellyfish in the Bering Sea and their ecological role in this productive shelf ecosystem. In Jellyfish Blooms; Pitt, K.A., Lucas, C.H., Eds.; Springer: Dordrecht, The Netherlands, 2014; pp. 153-183. ISBN 978-94-007-7014-0.

48. Haraldsson, M.; Båmstedt, U.; Tiselius, P.; Titelman, J.; Aksnes, D.L. Evidence of diel vertical migration in Mnemiopsis leidyi. PLoS ONE 2014, 9, e86595. [CrossRef]

49. Nogueira, M., Jr.; Brandini, F.P.; Codina, J.C.U. Diel vertical dynamics of gelatinous zooplankton (Cnidaria, Ctenophora and Thaliacea) in a subtropical stratified ecosystem (South Brazilian Bight). PLoS ONE 2015, 10, e0144161. [CrossRef]

50. Decker, M.B.; Breitburg, D.L.; Marcus, N.H. Geographical differences in behavioral responses to hypoxia: Local adaptation to an anthropogenic stressor? Ecol. Appl. 2003, 13, 1104-1109. [CrossRef]

51. Brandenberger, J.M.; Louchouarn, P.; Crecelius, E.A. Natural and post-urbanization signatures of hypoxia in two basins of Puget Sound: Historical reconstruction of redox sensitive metals and organic matter inputs. Aquat. Geochem. 2011, 17, 645-670. [CrossRef] 
52. Keister, J.E.; Tuttle, L.B. Effects of bottom-layer hypoxia on spatial distributions and community structure of mesozooplankton in a sub-estuary of Puget Sound, Washington, U.S.A. Limnol. Oceanogr. 2013, 58, 667-680. [CrossRef]

53. Decker, M.B.; Breitburg, D.; Purcell, J. Effects of low dissolved oxygen on zooplankton predation by the ctenophore Mnemiopsis leidyi. Mar. Ecol. Prog. Ser. 2004, 280, 163-172. [CrossRef]

54. Moriarty, P.; Andrews, K.; Harvey, C.; Kawase, M. Vertical and horizontal movement patterns of scyphozoan jellyfish in a fjord-like estuary. Mar. Ecol. Prog. Ser. 2012, 455, 1-12. [CrossRef]

55. Rice, C.A.; Duda, J.J.; Greene, C.M.; Karr, J.R. Geographic patterns of fishes and jellyfish in Puget Sound surface waters. Mar. Coast. Fish. 2012, 4, 117-128. [CrossRef]

(C) 2020 by the authors. Licensee MDPI, Basel, Switzerland. This article is an open access article distributed under the terms and conditions of the Creative Commons Attribution (CC BY) license (http://creativecommons.org/licenses/by/4.0/). 